\title{
Insulin resistance and thyroid hypofunction in obese women - A cross sectional study
}

\author{
Faraz Farishta* and Shaista Farishta \\ Department of Endocrinology, Sparsh Endocrinology and Diabetic Center, India
}

\begin{abstract}
We evaluated the relationship between thyroid hypofunction and insulin resistance among obese female patients visiting to endocrinology outpatient clinics (OPD) done at Sparsh Endocrinology \& Diabetic Center. In this cross-sectional study, a total of fifty female subjects with age group of 30-60 years, whose body mass index was above $30 \mathrm{~kg} / \mathrm{m} 2$ were studied for 16 months between July 2013 to November 2014 who were attending our endocrinology OPD were studied. Subjects with known disease or disorder of endocrine systems or who were receiving medications like, thyroid hormones preparations, Lithium, Amiodarone or corticosteroids were excluded. Blood samples were assed for T3, T4, TSH, FBS, Fasting Insulin and HOMA IR was calculated. A total of fifty subjects participated in the study. The mean age of the patients was $31.4 \pm 7.32$ years. Among these subjects TSH analysis revealed that $26 \%$ were having subclinical hypothyroidism (SCH). We found that $46 \%$ of these SCH subjects are having insulin resistance while $24 \%$ of patients with normal thyroid function are having insulin resistance as estimated by HOMA IR. $\mathrm{P}$-value $=0.6$ and the odds ratio is 0.667 , with a $95 \%$ confidence interval extending from 0.19 to 2.09 . The observed difference in insulin resistance was not statistically between the subjects with $\mathrm{SCH}$ and normal obese subjects. In our study we observed that insulin resistance co exists with thyroid-hypo function in $46 \%$ of obese subjects. Caution has to be executed in interpretation of results as our sample is small.
\end{abstract}

\section{Introduction}

Thyroid disease is widespread in women than men and women are five to eight times more likely to develop hypothyroidism. Thyroid illness can increase the risk of cardiovascular disease, infertility, and osteoporosis [1]. The association between thyroid function and body weight in euthyroid individuals has been given an important medical concern. The overt hypothyroidism $(\mathrm{OH})$ and sub-clinical hypothyroidism (SCH) are established risk factors for insulin resistance [2,3] and multiple studies have proved the association between insulin resistance, hypothyroidism and metabolic syndrome for overt hypothyroidism [4-7]. The prevalence of thyroid disease in patients with diabetes is significantly higher than that in the general population [8]. This indicates a possible interplay between thyroid status and insulin sensitivity. Bakker et al. [9] Chubb and Davis et al. [10] evaluated Insulin resistance augments the deleterious effect of hypothyroidism on the lipid profile and explained the complex interplay between thyroid function and insulin resistance in diabetic dyslipidemia [10]. To this purpose, we have evaluated the relationship between thyroid hypofunctionand insulin resistance amongobese female patients visiting to medical OPD.

\section{Materials and methods}

In this cross-sectional study, a total of fifty female subjects with age group of 30-60 years, whose body mass index was above $30 \mathrm{~kg} /$ $\mathrm{m}^{2}$ were studied for 16 months between July 2013 to November 2014 who were attending our Endocrinology OPD were studied. Subjects with known disease or disorder of endocrine systems or who were receiving medications like, thyroid hormones preparations, Lithium, Amiodaroneor corticosteroids were excluded. Participants underwent clinical and routine laboratory examination. From each patient five $\mathrm{ml}$ of blood sample was collected after an overnight fast of $>8 \mathrm{~h}$. Plasma glucose levels were measured using a hexokinase enzymatic reference method [11]. Fasting insulin levels were measured using a radioimmunoassay (RIA) method. HOMA-IR [12] was used to evaluate Insulin resistance (fasting serum insulin $(\mu \mathrm{U} / \mathrm{ml}) \times$ fasting plasma glucose $(\mathrm{mmol} / \mathrm{L}) /(22.5)$. A HOMA-IR value of 2.5 is taken as an indicator of IR in adults. Thyroid hormone assay was carried out by chemiluminiscence (CLIA) method [13] and the reference values g/dl. Patients with $\mu \mathrm{g} / \mathrm{ml} \mathrm{T} 4-5.13-14.06 \mu \mathrm{IU} / \mathrm{L}, \mathrm{T} 3-0.8-2.0 \mu \mathrm{IU} / \mathrm{L}$ in our laboratory were TSH: $0.4-4.5 \mu \mathrm{IU} / \mathrm{L}$. Sub clinical hypothyroidism is defined as normal T4 and T3 and TSH $>4.5 \mathrm{M} \mathrm{IU/L}$.

\section{Statistical analysis}

Data were entered into excel spread sheet 2007. Statistical analysis was performed using Graph pad prism version-5. Data was described as mean $\pm \mathrm{SD}$ or actual numbers \& percentages. To compare the frequency of variable among different groups chisquare analysis was used.

\section{Results}

A total of fifty subjects participated in the study. The mean age of the patients was $31.4 \pm 7.32$ years. Among these subjects TSH analysis revealed that $26 \%$ were having subclinical hypothyroidism (SH). We found that $46 \%$ of these $\mathrm{SH}$ subjects are having insulin resistance while $24 \%$ of patients with normal thyroid function are having insulin resistance as estimated by HOMA IR. P-value $=0.6$ and the odds ratio is 0.667 , with a $95 \%$ confidence interval

Correspondence to: Farazf Arishta, Department of Endocrinology, Sparsh Endocrinology and Diabetic Center, India, E-mail: drfarazfarishta@gmail.com

Key words: subclinical hypothyroidism, insulin resistance, obese woman, HOMA IR

Received: June 01, 2015; Accepted: July 02, 2015; Published: July 06, 2015 
Table 1. Observed difference in insulin resistance between the subjects with SH and normal obese subjects.

\begin{tabular}{|c|c|c|c|}
\hline Based on TSH & SH & Normal & P value \\
\hline $\mathrm{TSH}(\mu \mathrm{IU} / \mathrm{L})$ & $>4.5$ & $<4.5$ & $\mathrm{P}>0.05$-ns \\
\hline $\mathrm{n}$ & $13(26 \%)$ & $37(74 \%)$ & - \\
\hline Age $(\mathrm{yrs})$ & $33.21 \pm 6.14$ & $29.40 \pm 9.12$ & $\mathrm{~ns}$ \\
\hline HOMA IR & $6 / 13(46 \%)$ & $9 / 37(24 \%)$ & $\mathrm{ns}$ \\
\hline
\end{tabular}

extending from 0.19 to 2.09 . The observed difference ininsulin resistance was not statistically between the subjects with $\mathrm{SH}$ and normal obese subjects (Table 1).

\section{Discussion}

Now a day there was much interest on the influence of thyroid hormone action on insulin levels. The pathophysiological basis underlying glucose intolerance, dyslipidemia, abdominal obesity and hypertension has been attributed to insulin resistance [1,14]. Insulin resistance is a cardinal feature of type 2 diabetes mellitus and increased risk of dyslipidemia along with relatively frequently found mild thyroid dysfunction [15]. B M Singh et al. study illustrates the complex interplay between thyroid hormonal status and insulin levels in the pathogenesis of insulin resistance [16].

In the present study we have addressed the potential linkage among thyroid hypofunctionand insulin resistance in obese females and found that our results were supported by Hala A Abd El-Hafez, et al. [17] in their study that thyroid function and volume in PCOS women are significantly associated with BMI suggesting that obesity may represent a link between IR and thyroid changes in these women.

In conclusion, in our study we observed that insulin resistance co exists with thyroid-hypo function in $46 \%$ of obese subjects. Caution has to be executed in interpretation of results as our sample is small.

\section{References}

1. Meier C, Staub JJ, Roth CB, Guglielmetti M, Kunz M, et al. (2001) TSH-controlled L-thyroxine therapy reduces cholesterol levels and clinical symptoms in subclinical hypothyroidism: a double blind, placebo-controlled trial (Basel Thyroid Study). J Clin Endocrinol Metab 86: 4860-4866. [Crossref]

2. Serter R, Demirbas B, Korukluoglu B, Culha C, Cakal E, et al. (2004) The effect of L-thyroxine replacement therapy on lipid based cardiovascular risk in subclinical hypothyroidism. J Endocrinol Invest 27: 897-903. [Crossref]

3. Baskin HJ, Cobin RH, Duick DS, Gharib H, Guttler RB, et al. (2002) American
Association of Clinical Endocrinologists medical guidelines for clinical practice for the evaluation and treatment of hyperthyroidism and hypothyroidism. Endocr Pract 8: 457-469. [Crossref]

4. Garduño-Garcia Jde J, Alvirde-Garcia U, López-Carrasco G, Padilla Mendoza ME, Mehta R, et al. (2010) TSH and free thyroxine concentrations are associated with differing metabolic markers in euthyroid subjects. Eur J Endocrinol 163: 273-278. [Crossref]

5. Kumar HK, Yadav RK, Prajapati J, Reddy CV, Raghunath M, et al. (2009) Association between thyroid hormones, insulin resistance, and metabolic syndrome. Saudi Med J 30: 907-911. [Crossref]

6. Fommei E, Iervasi G (2002) The role of thyroid hormone in blood pressure homeostasis: evidence from short-term hypothyroidism in humans. J Clin Endocrinol Metab 87: 1996-2000. [Crossref]

7. Maratou E, Hadjidakis DJ, Kollias A, Tsegka K, Peppa M, et al. (2009) Studies of insulin resistance in patients with clinical and subclinical hypothyroidism. Eur $J$ Endocrinol 160: 785-790. [Crossref]

8. Reaven GM (1988) Banting lecture 1988. Role of insulin resistance in human disease Diabetes 37: 1595-1607. [Crossref]

9. Bakker SJ, ter Maaten JC, Popp-Snijders C, Slaets JP, Heine RJ, et al. (2001) The relationship between thyrotropin and low density lipoprotein cholesterol is modified by insulin sensitivity in healthy euthyroid subjects. J Clin Endocrinol Metab 86: 12061211. [Crossref]

10. Chubb SA, Davis WA, Inman Z, Davis TM (2005) Prevalence and progression of subclinical hypothyroidism in women with type 2 diabetes: the Fremantle Diabetes Study. Clin Endocrinol (Oxf) 62: 480-486. [Crossref]

11. Veiga F, Fernandes C, Teixeira F (2000) Oral bioavailability and hypoglycaemic activity of tolbutamide/cyclodextrin inclusion complexes. Int J Pharm 202: 165-171. [Crossref]

12. Antuna-Puente B, Disse E, Rabasa-Lhoret R, Laville M, Capeau J, et al. (2011) How can we measure insulin sensitivity/resistance? Diabetes Metab 37: 179-188. [Crossref]

13. Eshratkhah B, Sabri Nahand MR, Jafari Rad H, Pour Rasoul S, Seyyed Taj S (2010) Determination of plasma thyroid hormones by chemiluminescence and radioimmunoassay methods in calves. Global Vet 4: 554-557.

14. Bakker SJ, ter Maaten JC, Popp-Snijders C, Slaets JP, Heine RJ, et al. (2001) The relationship between thyrotropin and low density lipoprotein cholesterol is modified by insulin sensitivity in healthy euthyroid subjects. J Clin Endocrinol Metab 86: 12061211. [Crossref]

15. Perros P, McCrimmon RJ, Shaw G, Frier BM (1995) Frequency of thyroid dysfunction in diabetic patients: value of annual screening. Diabet Med 12: 622-627. [Crossref]

16. Singh BM, Goswami B, Mallika V (2010) Association between insulin resistance and hypothyroidism in females attending a tertiary care hospital. Indian J Clin Biochem 25: 141-145. [Crossref]

17. El-Hafez HAA, Elrakhawy MM, El-Aziz SA, El-Eshmawy MM (2013) Thyroid Function and Volume are Associated with Anthropometric Measurements and Insulin Resistance in Egyptian Women with Polycystic Ovary Syndrome. J Diabetes Metab 4: 288.

Copyright: (C2015 Arishta F. This is an open-access article distributed under the terms of the Creative Commons Attribution License, which permits unrestricted use, distribution, and reproduction in any medium, provided the original author and source are credited. 